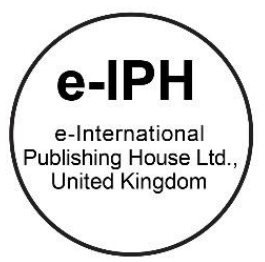

\title{
A Structural Equation Model of Improvement in Quality of Life in a Community-Based Development Projects in Nigeria
}

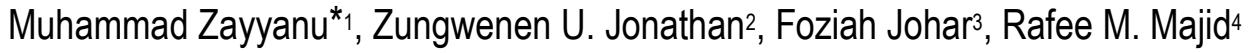 \\ ${ }^{1}$ Department of Urban and Regional Planning, Faculty of Built Environment, Universiti Teknologi Malaysia, 81310, Johor Bahru, Malaysia* \\ ${ }^{2}$ Department of Urban and Regional Planning, Faculty of Built Environment, Universiti Teknologi Malaysia, 81310, Johor Bahru, Malaysia, \\ ${ }^{3}$ Centre for Innovative Planning and Development, Faculty of Built Environment, Universiti Teknologi Malaysia, 81310, Johor Bahru, Malaysia, \\ ${ }^{4}$ Centre for Innovative Planning and Development, Faculty of Built Environment, Universiti Teknologi Malaysia, 81310, Johor Bahru, Malaysia
}

\begin{abstract}
Due to the lingering problem of poverty, many countries have adopted community-based development strategy towards improving the Quality of Life $(\mathrm{QoL})$ of their citizens. Numerous studies have focused on assessing QoL by measuring the manifested variables and ignored the significant contribution of some "latent" factors. Using Structural Equation Modelling (SEM), this paper investigated the factors that influence improvement in the QoL in a Community-based Poverty Reduction Project (CPRP) in Nigeria. The model indicates that the measured variables cause only $36 \%$ of the reduction in poverty of the project beneficiaries. The finding implies that there are other "hidden" factors responsible for the improvement in the quality of life.
\end{abstract}

(c) 2016. The Authors. Published for AMER ABRA by e-International Publishing House, Ltd., UK. This is an open access article under the CC BYNC-ND license (http://creativecommons.org/licenses/by-nc-nd/4.0/).

Peer-review under responsibility of AMER (Association of Malaysian Environment-Behaviour Researchers), ABRA (Association of Behavioural Researchers on Asians) and cE-Bs (Centre for Environment-Behaviour Studies), Faculty of Architecture, Planning \& Surveying, Universiti Teknologi MARA, Malaysia.

Keywords: Quality of Life, Community-based Development Projects, Poverty Reduction, Structural Equation Modelling

\section{Introduction}

Quality of life (QoL) is a broad concept (Marans 2012) that relates to the general welfare and prosperity of individuals (Abdul Karim 2012; Aklanoğlu \& Erdoğan 2012; Hanifah \& Hashim 2012; Mohit 2013b). Having realized its importance, many development theorists advocated for a QoL approach to local community development. They

\footnotetext{
* Corresponding author. Tel.: +60123085501

E-mail address: zmuhammed1140@gmail.com
}

2398-4287 @ 2016. The Authors. Published for AMER ABRA by e-International Publishing House, Ltd., UK. This is an open access article under the CC BY-NC-ND license (http://creativecommons.org/licenses/by-nc-nd/4.0/).

Peer-review under responsibility of AMER (Association of Malaysian Environment-Behaviour Researchers), ABRA (Association of Behavioural Researchers on Asians) and CE-Bs (Centre for Environment-Behaviour Studies), Faculty of Architecture, Planning \& Surveying, Universiti Teknologi MARA, Malaysia.

DOI: http://dx.doi.org/10.21834/e-bpj.v1i4.97 
argued that the application of community-based development approach would help local communities to improve their quality of life. The community-based strategy can bring about positive consequences to societal well-being and quality of life (Hamdan et al. 2014).

In line with the Millennium Development Goals (MDGs), many countries undertook commitments to reduce the proportion of poor people, whose income is less than $\$ 1$ a day (Chamhuri et al. 2012). Following a series of consultations between the World Bank and the Nigerian Government, the Community-based development program was adopted as a remedy for Poverty Alleviation in Nigeria. The program emphasizes the participation of local communities and civil societies in the planning, execution, and management of community-level projects. This initiative steered the establishment of the Kebbi-state Community-based Poverty Reduction Project (CPRP) in 2001. The target of the project is to improve the quality of life of the participating communities through poverty alleviation.

The objective of this paper is to investigate, using the structural equation modelling approach, the factors that influence improvement in the quality of life of community-based development project in Nigeria. Based on the theoretical framework for measurement of QoL and Poverty reduction, the paper developed a conceptual framework for measuring the influence of participation in a community-based development project in Nigeria. The findings of the study will widen the understanding of the multifarious factors responsible for the improvement in QoL of communitybased development projects.

\section{Literature Review}

\subsection{Framework for measurement of QoL}

The concept of quality of life has objective and subjective perspectives (Mohit 2013a; Ana-Maria 2015b). However, there is no single commonly accepted method for the measurement of quality of life (Rybakovas 2014). Due to its diverse nature, different authors employed different approaches to the measurement of QoL. While Marans (2003) and McCrea et al. (2006) emphasised on an objective approach that is not influenced by subjective opinion, (Veenhoven 2000) argues that QoL depends on individual perceptions. The objective approach focuses on the actual circumstances in which people live while the subjective approach reflects on individual's satisfaction and feelings about life situations (Muslim et al. 2013).

In the objective measurement, the evaluator measures what individuals consider being essential to their wellbeing. On the other hand, subjective QoL measures are concerned with the cognitive experience, feelings and behaviour dimensions of individuals (Mohit 2013a). Although, Veenhoven (2000) questioned the link between objective and subjective indicator, Michalos (2008) argues that a correct evaluation of the QoL must combine both subjective and objective measurement. Mohit (2013b) also favoured combining the two approaches so that the weakness of one will be complemented by the other.

Being a complex construct, QoL has many measurement indicators. For instance, the Australian Centre for Quality of Life identified over 1200 instruments that measure the quality of life (Ana-Maria 2015a). Juhásová (2015) adopted four domains (physical, psychological, social and environmental) which contribute to the overall of quality of life. Mohit $(2013 b)$ also adopted a framework that consists of 7 constructs to investigate variations in the QoL in Malaysia. These are communication and recreation, economic condition, educational facilities, environmental condition, health facilities, public safety and social status. Based on the multifaceted nature of QoL, Rybakovas (2014) observed that the overall individually perceived QoL consists of a set of latent (hidden) variables. These latent variables are dependent on the objective conditions (formative variables). Similarly, the empirically observed subjective indicators tend to reflect the values of latent (objective) variables, which are hidden to people's perception and experience (Maggino \& Zumbo 2012).

Numerous research studies have employed either the subjective or objective approaches for assessment of QoL. For instance, Noor \& Abdullah (2012) studied Quality of Work Life (QOWL) in a multinational firm in Malaysia using subjective parameters. Latif et al. (2013) investigated the effects of situational factors (subjective) on recycling behaviour to determine the QoL in Malaysia. Using objective approach, Mohit (2013a) studied regional variations in 
the QoL in Malaysia. However, despite numerous studies on the measurement of QoL, studies that empirically test the link between subjective (reflective) satisfaction with the objective improvement (formative) in QoL are limited (McCrea, R., Stimson, R. \& Marans 2011).

\subsection{Conceptualization and Measurement of Poverty}

A concise and universally acceptable definition of poverty is elusive largely because it affects many aspects of human conditions, including physical, moral and psychological well-being (Waheed 2012). Experts and academics used different criteria to conceptualize poverty. They describe poverty as starvation, severe malnutrition, illiteracy, substandard housing, clothing, and so forth. Poverty, in general, could be the lack of command over basic goods (Cavatassi et al. 2004) and the inability to achieve a socially minimum acceptable standard of living (World Bank 2000).

Waheed (2012) suggested various means for the measurement of Absolute poverty. They include poverty gap income shortfall, composite poverty measures, the physical quality of life index (PQOLI), the augmented physical quality of life index (PAQLI) and the human development index (HDI). On the other hand, relative poverty, often referred as subjective poverty, compares the living standards of those that are poor to a set of standards of the general population. Relative poverty is defined, in terms of a particular society, subject to a general standard of living and acceptable quality of living (Townsend 1993).

The approaches to measuring poverty have undergone refinement in the past decades. The Multidimensional Poverty Index (MPI), is an improvement over the previous measures of poverty. The MPI is a combination of indicators used to measure the development of nations, individuals and households regarding their multidimensional aspects of poverty and deprivation (Chamhuri et al. 2012). The MIP is superior because it identifies the core poor and estimate the individual level of poverty at the household level that other measures do not. It is estimated using ten indicators as a standard to measure poverty. The ten indicators are consistent with the three dimensions of the UNDP Human Development Index of Education, Health and Standard of living.

\subsection{Indicators for Measuring Community Participation and Poverty Reduction}

Numerous researchers have used various indicators for measurement of community participation and poverty reduction. Three constructs including participation in community development (PCD), Empowerment (EMP) and social capital (SOC) are employed in the measurement of community involvement. Poverty reduction (PVR), on the other hand, is measured using indicators that determine improved standard of living developed by Oxford Poverty and Human Development Initiative (University of Oxford 2010) (Table 1). 
Table 1. Constructs and measures used in the model

\begin{tabular}{|c|c|c|}
\hline Constructs & Variables & Source \\
\hline \multirow{5}{*}{$\begin{array}{l}\text { Participation in Community } \\
\text { Development (PCD) }\end{array}$} & Membership of Community & \multirow{5}{*}{$\begin{array}{l}\text { Narayan, (1995), CAG Consultants, (2009); Glass, } \\
\text { (1979) }\end{array}$} \\
\hline & $\begin{array}{l}\text { Organization, } \\
\text { Implementation of Projects }\end{array}$ & \\
\hline & Contribute Finance & \\
\hline & Contribute Materials & \\
\hline & Contribute Labour & \\
\hline \multirow[t]{5}{*}{ Empowerment (EMP) } & Awareness of Project & \multirow{5}{*}{$\begin{array}{l}\text { Braathen, (2000); Narayan-Parker, (2002); } \\
\text { Samah \& Aref, (2009) }\end{array}$} \\
\hline & Involvement in Community Meetings & \\
\hline & Contribute in Decision Making & \\
\hline & Supervision of Project & \\
\hline & Project Maintenance & \\
\hline \multirow[t]{5}{*}{ Social Capital (SOC) } & Solidarity and cooperation & \multirow{5}{*}{$\begin{array}{l}\text { Ferragina, Tomlinson, \& Walker, (2013); Woolcock \& } \\
\text { Narayan, (2000) }\end{array}$} \\
\hline & Give/receive community Assistance & \\
\hline & Enhanced community development & \\
\hline & Self-actualization & \\
\hline & Mutual trust & \\
\hline \multirow[t]{7}{*}{ Poverty Reduction (PVR) } & Number of visit to health facility & \multirow[t]{7}{*}{ The University of Oxford, (2010) } \\
\hline & Nutrition improved & \\
\hline & Children in primary school & \\
\hline & Children in secondary school & \\
\hline & Improved housing condition & \\
\hline & Access to services & \\
\hline & Asset ownership & \\
\hline
\end{tabular}

\subsection{Methodology}

Based on literature review and the underlying theoretical framework, this paper adopted a conceptual framework for measuring improvement in living standard of the project beneficiaries. The framework identified three constructs and fifteen variables for the measurement of community participation and seven indicators for measurement of poverty reduction (Fig 1).

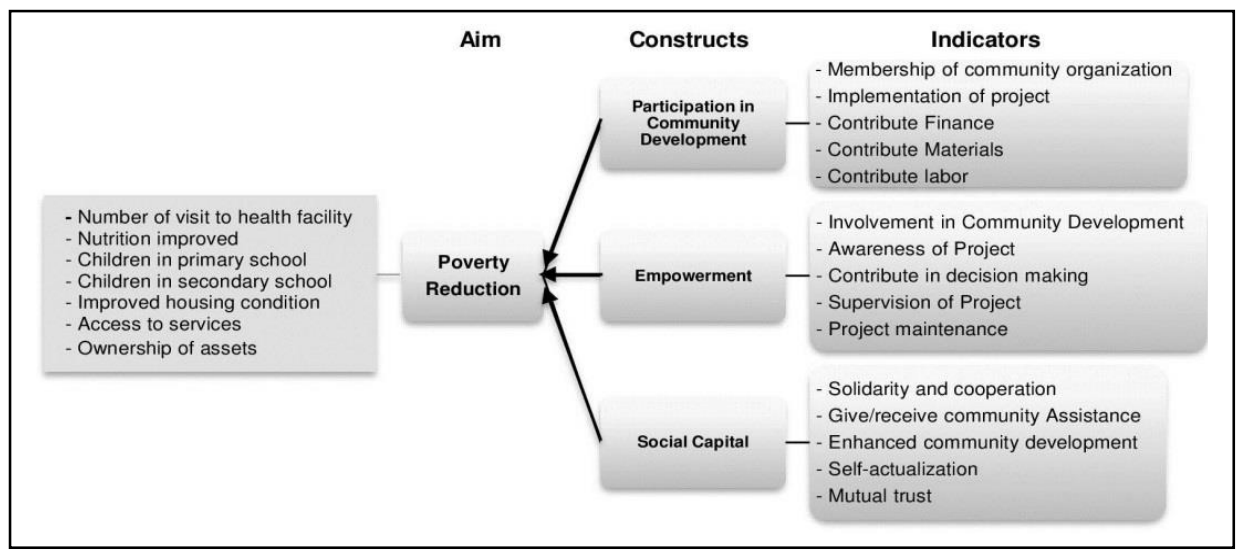

Figure 1. Conceptual framework for measuring poverty reduction 
The constructs in the conceptual framework for the study were adopted due to the fact that there seems to be an agreement on the variables and their respective indicators due to the degree of their being cited in numerous literature (Table 1). Based on the adopted framework, the authors selected two projects from each of the nine infrastructure sectors covered by the CPRP using stratified sampling procedure. Twenty households (ten each) from both participant and non-participants associated with the selected project are then randomly selected. The nonparticipants are to serve as a control group for the study. Accordingly, a total of 360 respondents were sampled for the study. However, the selection of samples for the study is limited by the availability of functional micro-projects. The limitation proceeded on the assumption that the CPRP would have impacted more on the communities with operating and functional micro-projects. The data was processed using SPSS and Structural Equation Modelling approach was employed to confirm the model and test the relationships using Amos software version 22.

\subsection{Results and Discussion}

\subsection{Exploratory Factor Analysis}

Exploratory Factor Analysis (EFA) was used to verify the internal reliability and validity of the research instrument. All the latent constructs achieve internal reliability with a Cronbach's Alpha of greater than 0.700 (Table 2). The factor loadings of the four constructs (PCD, EMP, SOC, and PVR) used in the study shows excellent reliability with all the twenty-two items. Similarly, the analysis shows a Kaiser-Meyer-Olkin (KMO) values of 0.866 , $0.804,0.817$ and 0.905 for PCD, EMP, SOC, and PVR respectively. These values indicate a common variance among the measured variables that ranges between $80 \%$ and $90 \%$ acceptable measure of sampling adequacy.

Table 2. Exploratory Factor Analysis (EFA)

\begin{tabular}{|c|c|c|c|c|c|}
\hline Construct & Items & $\begin{array}{l}\text { Factor } \\
\text { Loading }\end{array}$ & $\begin{array}{c}\text { Cronbach's } \\
\text { Alpha }\end{array}$ & $\begin{array}{l}\text { Number } \\
\text { of Items }\end{array}$ & $\begin{array}{c}\text { Internal } \\
\text { Reliability }\end{array}$ \\
\hline \multirow{7}{*}{$\begin{array}{l}\text { Participation in Community } \\
\text { Development (PCD) }\end{array}$} & PCD1 & 0.928 & \multirow{4}{*}{0.940} & \multirow{4}{*}{5} & \multirow{4}{*}{ Excellen } \\
\hline & PCD2 & 0.925 & & & \\
\hline & PCD3 & 0.921 & & & \\
\hline & PCD4 & 0.925 & & & \\
\hline & PCD5 & 0.930 & \multirow{7}{*}{0.788} & \multirow{7}{*}{5} & \multirow{7}{*}{ Excellent } \\
\hline & EMP1 & 0.770 & & & \\
\hline & EMP2 & 0.776 & & & \\
\hline \multirow[t]{5}{*}{ Empowerment (EMP) } & EMP3 & 0.709 & & & \\
\hline & EMP4 & 0.726 & & & \\
\hline & EMP5 & 0.752 & & & \\
\hline & SOC1 & 0.850 & & & \\
\hline & SOC2 & 0.831 & \multirow{3}{*}{0.876} & \multirow{3}{*}{5} & \multirow{3}{*}{ Excellent } \\
\hline \multirow[t]{5}{*}{ Social Capital (SOC) } & soc3 & 0.854 & & & \\
\hline & SOC4 & 0.851 & & & \\
\hline & SOC5 & 0.860 & \multirow{8}{*}{0.932} & \multirow{8}{*}{7} & \multirow{8}{*}{ Excellent } \\
\hline & QOL1 & 0.921 & & & \\
\hline & QOL2 & 0.922 & & & \\
\hline \multirow{5}{*}{ Poverty Reduction (PVR) } & QOL3 & 0.923 & & & \\
\hline & QOL4 & 0.917 & & & \\
\hline & QOL5 & 0.921 & & & \\
\hline & QOL6 & 0.918 & & & \\
\hline & QOL7 & 0.924 & & & \\
\hline
\end{tabular}




\subsection{Evaluating the Fitness of the Measurement Model}

Confirmatory Factor Analysis (CFA) is used to evaluate and validate the measurement model. It is employed to test whether the measures of a construct are consistent with the researcher's understanding of that constructs (Awang 2015). Every measurement model involving latent constructs needs to undergo CFA before modelling into SEM. However, due to the problems discovered when computing CFA separately for the individual constructs, Awang (2015) suggested the use of pooled CFA for all latent constructs simultaneously. The pooled CFA shows the fitness indexes of the model and confirms the achievement of the model.

Confirmatory Factor Analysis comprises of four stages: (1) defining the individual construct, (2) developing the overall measurement model, (3) designing a study to produce empirical results, and (4) assessing the model validity and reliability. In examining validity, three requirements of validity assessment must be achieved to the required level to achieve the model fit and to proceed to the structural model analysis. These include; convergent validity, Construct Validity, and Discriminant Validity. While, in assessing the reliability of the measurement model, Internal Reliability, Construct Reliability and Average Variance Extracted need to be evaluated.

There are several fit indexes for evaluating the fitness of the SEM models. Table 3 shows the recommended fit indexes and their respective acceptable values.

Table 3. Categories of Model Fit and their Level of Acceptance

\begin{tabular}{llll}
\hline Name of Category & Name of Index & \multicolumn{1}{c}{ Index Full Name } & Level of Acceptance \\
\hline Absolute Fit & Chi-Square & Discrepancy Chi Square & P-value $>0.05$ \\
RMSEA & $\begin{array}{l}\text { Root Mean Square of Error } \\
\text { Approximation }\end{array}$ & $<0.08$ \\
GFI & Goodness of Fit Index & $>0.90$ \\
AGFI & Adjusted Goodness of Fit & $>0.90$ \\
CFI & Comparative Fit Index & $>0.90$ \\
TLI & Tucker-Lewis Index & $>0.90$ \\
NFI & Normed Fit Index & $>0.90$ \\
CMIN (Chisq/df) & $\begin{array}{l}\text { Chi Square/Degree of } \\
\text { Freedom }\end{array}$ & $<3.0$ \\
\hline
\end{tabular}

The model in figure 2 generated 22 measurement variables that contain 253 sample moments. The degree of freedom for the model is 199 (253-54) and a chi-square goodness-of-fit statistics of 1152 . The fit indices in figure 2 shows that RMSEA=0.082, GFI=0.872, AGFI=0.840, CFI=0.910, TLI=0.897, NFI=0.893 and Chi-square/df=5.676. Apart from the CFI, the other fitness indexes in the pooled CFA do not meet the recommended value of acceptance. The option is to delete or correlate the redundant items in the model to achieve validity and reliability. 


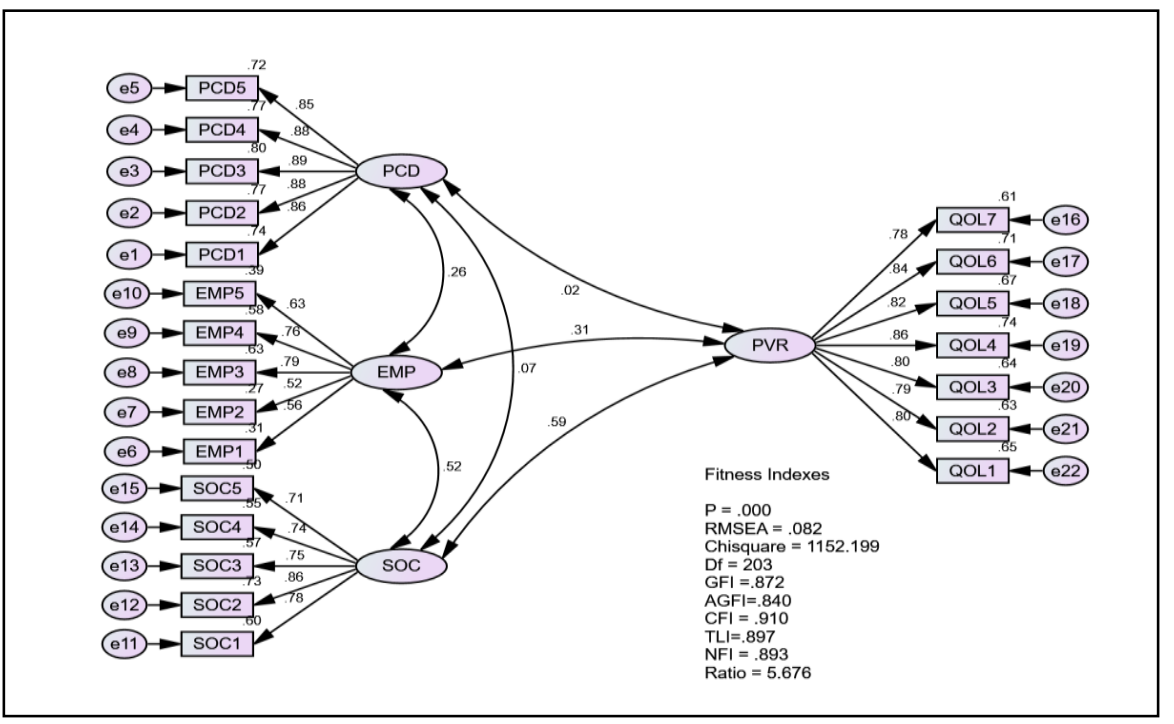

Figure 2. The measurement model

The model modification was carried out, and a new specified model was estimated. The modification indices show correlation between e1 (PCD1) and e2 (PCD2); and e14 (SOC4) and e15 (SOC5). As expected, correlating the redundant items improved the model leading to achievement of all the fitness indices. Figure 3 shows the model fitness indexes: RMSEA=0.052, GFI=0.932, AGFI $=0.914, \mathrm{CFI}=0.964, \mathrm{TLI}=0.959, \mathrm{NFI}=0.947$ and Chisq/df $=2.878$. The Chi-square goodness-of-fit model (572.730) is smaller compared with the Chi-square value of the original model (1152.199). The result of the modified pooled CFA shows a satisfactory fit model that achieved all the fit indexes. The re-specified measurement model meets the requirement of validity and reliability.

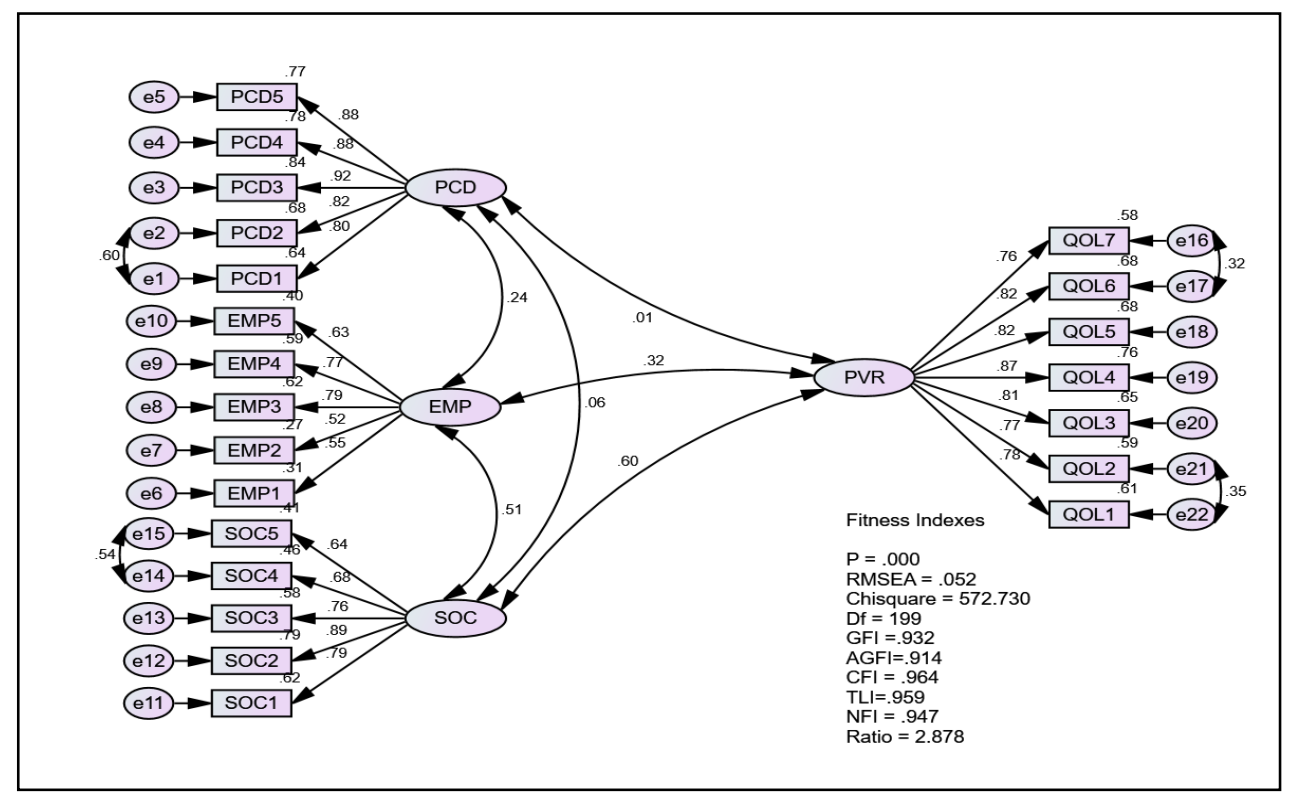

Figure 3. Modified measurement model 


\subsection{Assessing the Validity and Reliability of the Measurement Model}

The measurement properties (factor loading) of the model shown in Table 4 are adequate for each construct. Both the Composite Reliability (CR) and the Average Variance Extracted (AVE) are above 0.6 and 0.5 respectively. The model, therefore, achieved both "convergent" and "construct" validity adequately. The model also achieved discriminant validity as indicated in Table 5 . The bold and diagonal values are the square roots (AVE) while the other values are the correlations between the constructs. When all the diagonal values obtained are higher than the values in its row and column discriminant validity is achieved. Therefore, the discriminant validity of the model is achieved.

Table 4: CFA Result for the Construct in the Model

\begin{tabular}{|c|c|c|c|c|}
\hline Construct & Items & Factor Loading & $\mathrm{CR}(\geq 0.6)$ & $\operatorname{AVE}(\geq 0.5)$ \\
\hline \multirow[t]{5}{*}{ PCD } & PCD1 & 0.80 & & \\
\hline & PCD2 & 0.82 & & \\
\hline & PCD3 & 0.92 & 0.935 & 0.742 \\
\hline & PCD4 & 0.88 & & \\
\hline & PCD5 & 0.88 & & \\
\hline \multirow[t]{5}{*}{ EMP } & EMP1 & 0.55 & & \\
\hline & EMP2 & 0.52 & & \\
\hline & EMP3 & 0.79 & 0.779 & 0.501 \\
\hline & EMP4 & 0.77 & & \\
\hline & EMP5 & 0.63 & & \\
\hline \multirow[t]{5}{*}{ SOC } & SOC1 & 0.79 & & \\
\hline & SOC2 & 0.89 & & \\
\hline & soc3 & 0.76 & 0.869 & 0.573 \\
\hline & SOC4 & 0.68 & & \\
\hline & SOC5 & 0.64 & & \\
\hline \multirow[t]{7}{*}{ PVR } & QOL1 & 0.78 & & \\
\hline & QOL2 & 0.77 & & \\
\hline & QOL3 & 0.81 & & \\
\hline & QOL4 & 0.87 & 0.934 & 0.671 \\
\hline & QOL5 & 0.82 & & \\
\hline & QOL6 & 0.82 & & \\
\hline & QOL7 & 0.86 & & \\
\hline
\end{tabular}

Table 5: Summary of Discriminant Validity Index for the Constructs

\begin{tabular}{ccccc}
\hline Construct & PCD & EMP & SOC & PVR \\
\hline PCD & 0.86 & & & \\
EMP & 0.24 & 0.71 & & \\
SOC & 0.06 & 0.51 & 0.76 & 0.82 \\
PVR & 0.01 & 0.32 & 0.60 & \\
\hline
\end{tabular}

\subsection{Structural Equation Model (SEM)}

In figure 4 the structural path model is presented and evaluated. The model explained $36 \%$ of the variance accounted for by the joint influence of the predictors (participation in community development, empowerment, and social capital). This result implies that the combined influence of the variables of community involvement in poverty reduction is $36 \%$ while $64 \%$ does not influence poverty alleviation. However, among the three factors, social capital has a more significant influence (0.59) on the relationship. The influence of social capital on poverty reduction is also buttressed by (Okunamadewa et al. 2005), (Dschang 2009), and (Santini et al. 2012). 


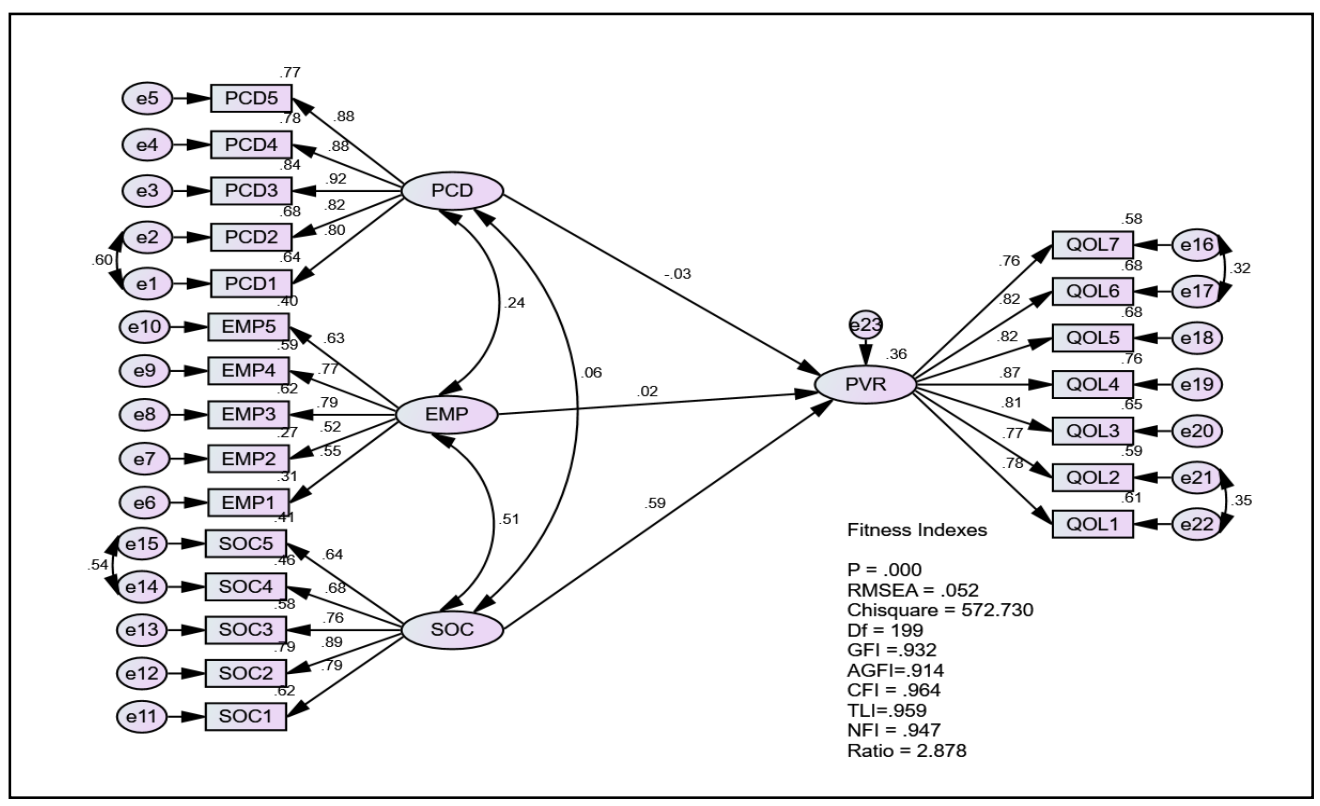

Figure 4. Model predicting poverty reduction

Similarly, only one of the paths (SOC) out of the three linking the independent variables (PCD, EMP, and SOC) to the dependent variable (PVR) is significant at the critical ratio test $(> \pm 1.96, p<0.05)$. The probability of getting a critical ratio as large as 11.721 in absolute value is less than 0.001 (Table 6). In other words, the regression weight for SOC in the prediction of PVR is significantly different from zero at the 0.001 level (two-tailed).

Table 6. Regression weights for path estimate

\begin{tabular}{ccccc}
\hline Path & Estimate $(\beta)$ & C.R & P-Value & Result \\
\hline PVR <--- PCD & -0.028 & -0.777 & 0.437 & Not significant \\
PVR<--- EMP & 0.037 & 0.436 & 0.663 & No significant \\
PVR<--- SOC & 0.604 & 11.721 & $* * *$ & Significant \\
\hline
\end{tabular}

Poverty, being a multi-dimensional construct, has multiple cause-effect relationships. The $64 \%$ of the poverty reduction that could not be explained by the model could be caused by other "hidden" factors other than those associated with community involvement. This implies that the lingering problems of poverty in developing countries are so complex that they cannot be solved by a community-based poverty reduction program alone. Investment in both physical and social infrastructure is necessary to reduce poverty (Ogun 2010). As observed by Hewett \& Montgomery (2001), the inadequate provision of public services can stalemate efforts to reduce poverty. For instance, lack of adequate water supply and sanitation can cause elevated health risks to households; firms and small-scale enterprises lacking electricity face higher production costs.

\section{Conclusion}

The paper assessed the influence of community participation on poverty reduction towards enhancing the quality of life of the project beneficiaries. The study developed a model of improvement in Quality of Life for a Community- 
based poverty reduction project in Nigeria. The finding of the study revealed a complimentary influence of the three dimensions of community involvement (community participation, empowerment, and social capital) in poverty reduction in Kebbi state, Nigeria.

However, the findings of the study indicate that community participation accounted for only $36 \%$ of the poverty reduction of the project's beneficiaries. The authors, therefore, recommend the adoption of appropriate poverty reduction strategies that are based on the multidimensional nature of poverty in developing countries. Future research agenda may wish to explore other poverty alleviation measures towards improving the quality of life of the poor. Such research agendas may focus on investigating other pro-poor driven natural sector like agriculture to complement community-based development projects in developing countries. Since majority of poor people used agriculture as their primary source of income, focusing poverty reduction on the sector can have tremendous impact on reduction of poverty.

\section{References}

Abdul Karim, H., 2012. Low-Cost Housing Environment: Compromising Quality of Life? Procedia - Social and Behavioral Sciences, 35(December 2011), pp.44-53.

Aklanoğlu, F. \& Erdoğan, E., 2012. Improvement Quality of Life for an Anatolian Traditional Settlement: Konya-Sille Case. Procedia - Social and Behavioral Sciences, 35(December 2011), pp.420-430.

Ana-Maria, V., 2015a. Satisfaction of Participants in Physical Activity Programs as an Indicator of Quality of Life. Procedia - Social and Behavioral Sciences, 180(November 2014), pp.1434-1438.

Ana-Maria, V., 2015b. Study on Promoting Quality of Life Through Physical Exercise. Procedia - Social and Behavioral Sciences, 180, pp.14391443. Awang, Z., 2015. SEM Made Simple First., MPWS Rich Publication Sdn. Bhd. (1132290-K).

Braathen, E., 2000. Attacking Poverty. Forum for Development Studies, 27(2), pp.331-350.

CAG Consultants, 2009. Participation : A theoretical context. , (1969), pp.1-13.

Cavatassi, R., Davis, B. \& Lipper, L., 2004. Estimating poverty over time and space : Construction of a time-variant poverty index for Costa Rica. , (04), p.29.

Chamhuri, N.H., Karim, H.A. \& Hamdan, H., 2012. Conceptual Framework of Urban Poverty Reduction : A review of literature. Procedia - Social and Behavioral Sciences, 68, pp.804-814.

Dschang, P.O.B., 2009. Does Social Capital determine Poverty ? Evidence from Cameroon Household., University of Dschang, Faculty of Economics and Management

Ferragina, E., Tomlinson, M. \& Walker, R., 2013. Poverty, Participation and Choice: The Legacy of Peter Townsend. , (May 2013), pp.1-69.

Glass, J.J., 1979. Citizen participation in planning: the relationship between objectives and techniques. Journal of the American Planning Association. American Planning Association, 45(2), pp.180-189.

Hamdan, H., Yusof, F. \& Marzukhi, M.A., 2014. The Social Capital and Quality of Life in Urban Neighborhoods High Density Housing. In Procedia - Social and Behavioral Sciences. Elsevier B.V., pp. 169-179.

Hanifah, N.A. \& Hashim, R., 2012. The Madrid Protocol 1991 and its Environmental Impacts towards the Quality of Life. Procedia - Social and Behavioral Sciences, 35(December 2011), pp.398-403.

Hewett, P.C. \& Montgomery, M., 2001. Poverty and Public Services in Developing-Country Cities, New York: Population Council.

Juhásová, A., 2015. Comparison of Quality of Life of Families with Children with Disability and Families with Children without Disability. Procedia - Social and Behavioral Sciences, 174, pp.3378-3384.

Latif, S. et al., 2013. Analyzing the Effect of Situational Factor on Recycling Behaviour in Determining the Quality of Life. Journal of Asian Behavioral Studies, 3(8), pp.37-46. 
Maggino, F. \& Zumbo, B.D., 2012. Measuring the quality of life and the construction of social indicators. In K. C. Land, A. C. Michalos, \& M. J. Sirgy, eds. Handbook of social indicators and quality of life research. Springer, pp. 201-238.

Marans, R.W., 2012. Quality of Urban Life Studies: An Overview and Implications for Environment-Behaviour Research. Procedia - Social and Behavioral Sciences, 35(December 2011), pp.9-22.

Marans, R.W., 2003. Understanding environmental quality through quality of life studies: the 2001 DAS and its use of subjective and objective indicators. Landscape and Urban Planning, 65(1-2), pp.73-83.

McCrea, R., Shyy, T.K. \& Stimson, R., 2006. What is the strength of the link between objective and subjective indicators of urban quality of life? Applied Research in Quality of Life, 1(1), pp.79-96.

McCrea, R., Stimson, R. \& Marans, R.W. (2011)., 2011. The evolution of integrative approaches to the analysis of quality of urban life. In R. J. S. (Eds. . R. W. Marans, ed. Investigating quality of urban life: Theory, methods and empirical research. Springer, pp. 77-106.

Michalos, A.C., 2008. Education, happiness and wellbeing. Social Indicators Research, 87(3), pp.347-366.

Mohit, M.A., 2013a. Objective Analysis of Variation in the Regional Quality of Life in Malaysia and its Policy Implications. Procedia - Social and Behavioral Sciences, 101, pp.454-464.

Mohit, M.A., 2013b. Quality of Life in Natural and Built Environment - An Introductory Analysis. Procedia - Social and Behavioral Sciences, 101, pp.33-43.

Muslim, M.H., Karim, H.A. \& Abdullah, I.C., 2013. Well-Being of UiTM Shah Alam Students Living in Off-Campus Environment. Asian Journal of Envoronment-Behaviour Studies, 4(13), pp.147-158.

Narayan, D., 1995. Designing community based development. , (4).

Narayan-Parker, D., 2002. Empowerment and Poverty Reduction: A Sourcebook. , p.371.

Noor, S.M. \& Abdullah, M.A., 2012. Quality Work Life among Factory Workers in Malaysia. Procedia - Social and Behavioral Sciences, 35(December 2011), pp.739-745.

Ogun, T.P., 2010. Infrastructure and Poverty Reduction: Implications for Urban Development in Nigeria. Working Paper Series.

Okunamadewa, F.Y., Yusuf, S.A. \& Omonona, B.T., 2005. Social Capital and Poverty Reduction in Nigeria. , pp.1-47.

Rybakovas, E., 2014. Cause-effect Relationships Between Objective and Subjective Measures of Quality of Life in Lithuania Municipalities. Procedia - Social and Behavioral Sciences, 156(April), pp.83-87.

Samah, A.A. \& Aref, F., 2009. People 's Participation in Community Development : A Case Study in a Planned Village Settlement in Malaysia. World Rural Observations, 1(2), pp.45-54.

Santini, I., Pascale, A. De \& La, R., 2012. Social Capital and Household Poverty : the Case of European Union Social Capital and Household Poverty : the Case of European Union (December).

Townsend, P., 1993. Conceptualising poverty. The international analysis of poverty, pp.25-39.

University of Oxford, 2010. Oxford Poverty and Human Development Initiative (OPHI) Country Briefing : Ethiopia. , (June), pp.1-4.

Veenhoven, R., 2000. The four qualities of life: Ordering Concepts and Measures of the Good Life. Journal of happiness studies, 1, pp.1-39.

Waheed, O.O., 2012. Concept, Measurement and Causes of Poverty: Nigeria in Perspective. American Journal of Economics, 2, pp.25-36.

Woolcock, M. \& Narayan, D., 2000. Social Capital: Implications for Development Theory, and Policy. World Bank Research Observer, 15, No. 2(August), pp.225-249.

World Bank, 2000. World Development Report 2000/2001: Attacking Poverty, Oxford. 